\title{
Short-term effect of intravenous methylprednisolone pulse therapy on glycemic control in patients with normoglycemia and pre-diabetes
}

\section{Katarzyna Mitkowska}

Department of Internal Medicine and Endocrinology, Medical University of Warsaw, Warsaw, Poland

(D) https://orcid.org/0000-0003-3772-6174

\section{Katarzyna Pelewicz}

Department of Internal Medicine and Endocrinology, Medical University of Warsaw, Warsaw, Poland

(iD) https://orcid.org/0000-0002-2333-2337

\section{Izabela Walasik}

Student's Scientific Circle "Endocrinus", Department of Internal Medicine and Endocrinology, Medical University of Warsaw

(iD) https://orcid.org/0000-0003-2908-0908

\section{Sebastian Szewczyk}

Student's Scientific Circle "Endocrinus", Department of Internal Medicine and Endocrinology, Medical University of Warsaw

(iD) https://orcid.org/0000-0001-5511-5823

\section{Piotr Miśkiewicz}

Department of Internal Medicine and Endocrinology, Medical University of Warsaw, Warsaw, Poland

(iD) https://orcid.org/0000-0003-4015-6491

Corresponding author: piotr.miskiewicz@wum.edu.pl
DOI: https://doi.org/10.20883/medical.e435

Keywords: Graves' orbitopathy, glucocorticoids, methylprednisolone, glycemia, hyperglycemia

Published: 2020-06-30

How to Cite: Mitkowska K, Pelewicz K, Walasik I, Szewczyk S, Miśkiewicz P. Short-term effect of intravenous methylprednisolone pulse therapy on glycemic control in patients with normoglycemia and pre-diabetes. JMS [Internet]. 2020 Jun 30;89(2):e435. doi:10.20883/medical.e435

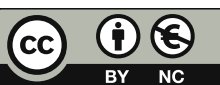

(C) 2020 by the author(s). This is an open access article distributed under the terms and conditions of the Creative Commons Attribution (CC BY-NC) licencse. Published by Poznan University of Medical Sciences

\section{ABSTRACT}

Introduction. Systemic steroid therapy leads to disturbances in carbohydrate metabolism. The effect of immunosuppression with intravenous methylprednisolone (IVMP) pulses on glycaemia is not conclusive. Aim. This study aimed to assess the short-term effect of IVMP therapy in moderate-to-severe Graves' orbitopathy (GO) on glycaemic control in normoglycaemic patients with and without pre-diabetes.

Material and Methods. Twenty-five GO patients treated with IVMP pulses (at initial dose of $6 \times 0.5 \mathrm{~g}$ once a week, followed by $0.25 \mathrm{~g}$ given for 6 consecutive weeksweekly) were recruited and divided into a normoglycaemic group $(n=15$, patients without pre-diabetes) and a pre-diabetic group $(n=10$, patients with impaired fasting glycaemia (IFG) and/or impaired glucose tolerance (IGT)). Six daily capillary blood glucose measurements were performed at fixed times the day before and on the day of the first pulse administration.

Results. There was a significant increase in the glucose concentration on the day of IVMP administration in both groups of patients compared to the day before drug administration, with $50 \%$ of patients showing an increase in blood glucose above $200 \mathrm{mg} / \mathrm{dl}$. There were no statistically significant differences between the two groups.

Conclusions. Methylprednisolone in a high intravenous dose has a tremendous impact on the blood glucose level in normoglycaemic and pre-diabetic patients on the day of drug administration. 


\section{Introduction}

Therapy with high-dose intravenous glucocorticoids (GCs) is widely and effectively used to treat a variety of inflammatory and autoimmune diseases $[1,2]$. It is considered as the first-line treatment for moderate-to-severe and active Graves' orbitopathy (GO) by the European Group on Graves' Orbitopathy (EUGOGO) [3]. Intravenously administered GCs are more effective and better tolerated than oral GCs [2-5], however, there is still a risk of serious side effects, e.g. pulmonary embolism, myocardial infarction, severe cerebrovascular events, acute liver damage and sudden death, as well as changes in coagulation status and blood pressure [2,3,5-9]. One of the described side effects is hyperglycaemia, with the influence of GCs on glucose homeostasis being complex. Mechanisms of glucocorticoid-induced diabetes mellitus (DM) include increased insulin resistance, destruction of pancreatic cells, $\beta$-cell dysfunction, impaired insulin release, impaired suppres-

Table 1. Summary of studies that investigated glycaemia during intravenous methylprednisolone pulse therapy

\begin{tabular}{|c|c|c|c|c|c|c|c|}
\hline 充 & 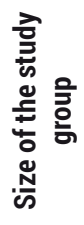 & $\begin{array}{l}\frac{\infty}{5} \\
\frac{0}{0} \\
\frac{\pi}{0}\end{array}$ & 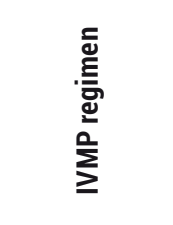 & 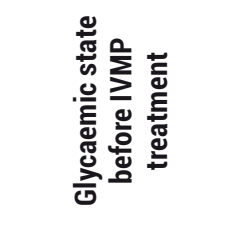 & 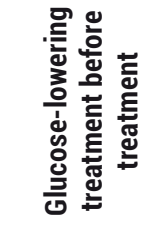 & 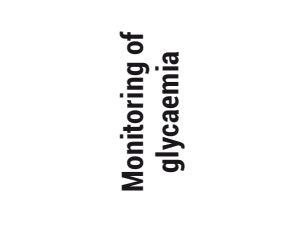 & 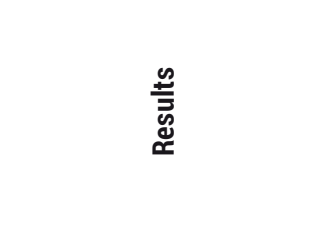 \\
\hline $\begin{array}{l}\text { Feldman- } \\
\text { Billard et } \\
\text { al. [12] }\end{array}$ & 224 & $\begin{array}{l}\text { AON, } \\
\text { SU, } \\
\text { OIN, } \\
\text { CGR, } \\
\text { other }\end{array}$ & $\begin{array}{l}250,500 \text { or } \\
1000 \text { mg of } \\
\text { IVMP a day } \\
\text { for } 3 \\
\text { consecutive } \\
\text { days }\end{array}$ & $\begin{array}{l}\text { Patients with and } \\
\text { without known DM } \\
\text { history } \\
\text { Group of patients } \\
\text { without DM } \\
\text { consisted of } \\
\text { normoglycaemic } \\
\text { and pre-diabetic } \\
\text { patients }\end{array}$ & $\begin{array}{l}\text { All but } 1 \\
\text { patient with } \\
\text { DM were } \\
\text { treated with } \\
\text { either oral } \\
\text { glucose- } \\
\text { lowering } \\
\text { agents or } \\
\text { insulin }\end{array}$ & $\begin{array}{l}\text { mFBG was measured in } \\
\text { all subjects before and } \\
\text { after each pulse. In } \\
\text { subjects with DM, self- } \\
\text { monitoring of capillary } \\
\text { blood glucose was } \\
\text { performed at least } 3 \\
\text { times per day before } \\
\text { each meal }\end{array}$ & $\begin{array}{l}\text { Patients without DM } \\
\text { showed a } 50 \% \text { increase in } \\
\text { mFBG after } 1^{\text {st }} \text { pulse } \\
\text { Diabetic patients showed } \\
\text { a } 44 \% \text { increase in } \mathrm{mFBG} \\
\text { after the } 1^{\text {st }} \text { pulse }\end{array}$ \\
\hline $\begin{array}{l}\text { Tanaka et. } \\
\text { al. [16] }\end{array}$ & 5 & $\mathrm{GO}$ & $\begin{array}{l}500 \mathrm{mg} \text { of } \\
\text { IVMP - } 3 \\
\text { cycles of } 3 \\
\text { days a week }\end{array}$ & $\begin{array}{l}\text { Patients without } \\
\text { known DM history } \\
\text { and normal } \\
\text { glucose tolerance }\end{array}$ & - & $\begin{array}{l}\text { Continuous blood } \\
\text { glucose monitoring }\end{array}$ & $\begin{array}{l}\text { Glucose levels increased } \\
\text { from } 4 \text { hours after the } \\
\text { administration of IVMP } \\
\text { up to midnight, then } \\
\text { gradually decreased until } \\
\text { morning. The highest } \\
\text { glucose level was after } \\
\text { dinner, exceeding } 200 \\
\text { mg/dl ( } 240-293 \mathrm{mg} / \mathrm{dL}) \\
\text { in all patients. }\end{array}$ \\
\hline
\end{tabular}

$A O N$ acute optic neuritis, SU severe uveitis, OIN ocular infectious diseases, CGR corneal graft rejection, SLE systemic lupus erythematosus, ITP idiopathic thrombocytopenic purpura, MS multiple sclerosis, AHA autoimmune haemolytic anaemia, GO Graves' orbitopathy, IVMP intravenous methylprednisolone pulse, $D M$ diabetes mellitus, $m F B G$ morning fasting blood glucose 
sion of hepatic glucose production and inhibited glycogenesis [10,11]. Only a few studies assessed the influence of intravenous methylprednisolone (IVMP) on glucose tolerance (Table 1) [12-16]. Moreover, most studies did not compare patients without diabetes (non-diabetic) to patients with diabetes [12,14]. Some authors suggest that the effect of the IVMP therapy on glucose tolerance in non-diabetic patients is transient and has no clinical relevance, thus these patients do not need any glucose-lowering treatment [12], while others believe that there is evidence that acute hyperglycaemia is a cardiovascular risk factor, independent of the presence of previous diabetes $[14,17-$ 19]. Acute hyperglycaemia is associated with an increase in LDL cholesterol oxidation, impaired endothelial function, activation of the coagulation cascade, increased production of pro-inflammatory cytokines and oxidative stress. Therefore, this study aimed to evaluate the short-term influence of IVMP therapy in moderate-to-severe GO on glucose tolerance in patients with normoglycaemia and those with pre-diabetes (impaired fasting glycaemia (IFG) and/or impaired glucose tolerance (IGT)) prior to treatment.

\section{Material and Methods}

\section{Patients}

The study was conducted at one academic referral centre in the Medical University of Warsaw (WUM). Patients with active, moderate-to-severe GO according to the EUGOGO classification were admitted to the Department of Endocrinology for IVMP therapy from 2012 to 2016 . The study included 25 patients: 20 patients with Graves' disease, 4 patients with Hashimoto's thyroiditis and

Table 2. Basic characteristics of patients $(n=25)$

Number of patients $(\%)$ or mean \pm SD range

\begin{tabular}{|c|c|c|c|}
\hline \\
\hline & Normoglycaemic & Pre-diabetic & $p$-value \\
\hline Number of patients & $15(60 \%)$ & $10(40 \%)$ & \\
\hline Impaired fasting glucose & $0(0 \%)$ & $10(100 \%)$ & \\
\hline Fasting plasma glucose (normal range - lower than $100 \mathrm{mg} / \mathrm{dl}$ ) & $90 \pm 4.92(81-98)$ & $110 \pm 16.17(100-152)$ & 0.00003 \\
\hline Impaired glucose tolerance & $0(0 \%)$ & $5(50 \%)$ & \\
\hline $\begin{array}{l}\text { Blood plasma glucose in } 2 \mathrm{~h} \text { oral glucose tolerance test (normal } \\
\text { range - lower than } 140 \mathrm{mg} / \mathrm{dl} \text { ) }\end{array}$ & $97 \pm 20.3(68-133)$ & $134 \pm 47.86(61-192)$ & 0.1 \\
\hline \multicolumn{4}{|l|}{ Thyroid disease } \\
\hline Graves' disease treated for hyperthyroidism & $10(67 \%)$ & $6(60 \%)$ & 1 \\
\hline Graves' disease after radical treatment on levothyroxine & $2(13 \%)$ & $1(10 \%)$ & 1 \\
\hline Euthyroid Graves' & $0(0 \%)$ & $1(10 \%)$ & 0.4 \\
\hline Hashimoto thyroiditis on levothyroxine & $3(20 \%)$ & $1(10 \%)$ & 0.6 \\
\hline Orbitopathy of unknown aetiology & $0(0 \%)$ & $1(10 \%)$ & 0.4 \\
\hline \multicolumn{4}{|l|}{ Sex } \\
\hline Women & $9(60 \%)$ & $8(80 \%)$ & 0.4 \\
\hline Men & $6(40 \%)$ & $2(20 \%)$ & 0.4 \\
\hline Age (years) & $50 \pm 10(35-77)$ & $59 \pm 10(43-74)$ & 0.07 \\
\hline Body mass index $\left(\mathrm{kg} / \mathrm{m}^{2}\right)$ & $25 \pm 4(20-34)$ & $26 \pm 5(16-33)$ & 0.7 \\
\hline Current smokers & $7(47 \%)$ & $2(20 \%)$ & 0.2 \\
\hline Past smokers & $5(33 \%)$ & $3(30 \%)$ & 1 \\
\hline Non-smokers & $3(20 \%)$ & $5(50 \%)$ & 0.2 \\
\hline TSH (normal range: $0.27-4.2 \mu \mathrm{lU} / \mathrm{mL}$ ) & $2.83 \pm 1.63(0.52-6.25)$ & $1.78 \pm 1.68(0.008-5.81)$ & 0.2 \\
\hline fT4 (normal range $12.0-22.0 \mathrm{pmol} / \mathrm{L}$ ) & $16.28 \pm 3.6(12.1-20.9)$ & $18.64 \pm 3.73(12.91-21.96)$ & 0.1 \\
\hline fT3 (normal range: $3.1-6.8 \mathrm{pmol} / \mathrm{L}$ ) & $4.76 \pm 0.93(3.2-6.6)$ & $5.16 \pm 0.86(3.36-6.48)$ & 0.3 \\
\hline Median CAS & 4.0 & 4.5 & 0.8 \\
\hline \multicolumn{4}{|l|}{ Comorbidity } \\
\hline Hypertension & $5(33 \%)$ & $4(40 \%)$ & 1 \\
\hline Hypercholesterolemia & $1(6 \%)$ & $1(10 \%)$ & 1 \\
\hline Diabetes mellitus & $0(0 \%)$ & $0(0 \%)$ & \\
\hline Oral GCs & $0(0 \%)$ & $0(0 \%)$ & \\
\hline Hypoglycaemic drugs & $0(0 \%)$ & $0(0 \%)$ & \\
\hline
\end{tabular}


1 patient with orbitopathy of unknown aetiology. In total, 16 patients were treated with antithyroid drugs (alone or according to a "block and replace" schedule) and 7 patients received levothyroxine: 3 patients with Graves' disease who were at least 6 months after the last radical treatment (radioiodine therapy or thyroidectomy) and 4 patients with Hashimoto's thyroiditis, 1 patient had euthyroid Graves' disease. The inclusion criteria consisted of (1) active, moderate-to-severe GO; (2) age $\geq 18$ years and (3) euthyroidism for at least 1 month. Exclusion criteria were: (1) treatment with oral GCs within the last six months; (2) any other treatment known to significantly alter carbohydrate metabolism (e.g., glucose-lowering drugs) and (3) a clinical diagnosis of diabetes mellitus. Depending on the state of carbohydrate metabolism, patients were divided into two groups: a normoglycaemic group ( $n=15$, patients without pre-diabetes) and a pre-diabetic group $(n=10$, patients with IFG and/or IGT). Diagnosis of pre-diabetes was based on fasting plasma glucose higher than or equal to $100 \mathrm{mg} / \mathrm{dl}$ but lower than $126 \mathrm{mg} / \mathrm{dl}$ and/ or blood plasma glucose higher or equal to $140 \mathrm{mg} / \mathrm{dl}$ but lower than $200 \mathrm{mg} / \mathrm{dl}$ in the second hour of oral glucose tolerance test [20]. Clinical characteristics of both groups are shown in Table 2. The study was approved by the Bioethics Committee of the Medical University of Warsaw.

\section{Study design}

All patients received IVMP therapy according to the EUGOGO recommendations: starting at a dose of $0.5 \mathrm{~g}$ once weekly for 6 weeks, followed by $0.25 \mathrm{~g}$ once weekly for 6 weeks ( $4.5 \mathrm{~g}$ cumulative dose). The analysis was performed during the 1st IVMP administration, with an IVMP pulse infusion of 4 hours from 11:00 to 15:00 for all patients. In both groups, six daily capillary blood glucose measurements (glycaemic profile) were performed at fixed times $(6: 00,11: 00,15: 00,19: 00$, $22: 00,2: 00)$ the day before and on the day of the 1st IVMP pulse administration. Patients received a diet consisting of three meals at 9:00, 13:00 and 17:00, with the measurement at 6:00 indicating fasting glucose and measurements at 11:00, 15:00 and 19:00 indicating the glucose level 2 hours after a meal. Capillary blood glucose measurements were analysed using a Glucomaxx glucose meter (Genexo, Warsaw, Poland).

\section{Statistical analysis}

All analyses were performed using STATISTICA software ver. 13.3 (StatSoft Polska, Cracow, Poland). Continuous variables are expressed as mean \pm standard deviation (SD) or median values. Categorical data were presented as numbers ( $n$ ) or percentages (\%). Comparisons between blood glucose measurements were performed using paired t-tests. Differences between both groups (normoglycaemic and pre-diabetic) were compared using the Mann-Whitney $U$ test. A p-value $<0.05$ was deemed statistically significant.

\section{Results}

\section{Evaluation before intervention}

Baseline mean values of six daily capillary blood glucose measurements on the day before the administration of $500 \mathrm{mg}$ IVMP are shown in Table 3. In all patients in the normoglycaemic group, glycaemia remained lower than $200 \mathrm{mg} / \mathrm{dl}$ during the day. In one patient (10\%) from the prediabetic group, glycaemia higher than $200 \mathrm{mg} / \mathrm{dl}$ was observed during the day.

Table 3 Changes in glucose concentrations during intravenous methylprednisolone pulse $(0.5 \mathrm{~g})$

\begin{tabular}{ccccccc} 
& \multicolumn{3}{c}{ Normoglycaemic group } & \multicolumn{3}{c}{ Pre-diabetic group } \\
\hline Time of measurement & Day before & Day of the pulse & $\boldsymbol{p}$-value & Day before & Day of the pulse & $\boldsymbol{p}$-value \\
\hline $6: 00$ & $88 \pm 6$ & $89 \pm 12$ & 0.77 & $93 \pm 10$ & $90 \pm 12$ & 0.5 \\
\hline $11: 00$ & $110 \pm 31$ & $106 \pm 21$ & 0.6 & $95 \pm 24$ & $102 \pm 26$ & 0.6 \\
\hline $15: 00$ & $114 \pm 26$ & $143 \pm 34$ & 0.057 & $100 \pm 14$ & $148 \pm 28$ & 0.007 \\
\hline $19: 00$ & $116 \pm 20$ & $204 \pm 44(130-$ & 0.00003 & $104 \pm 25$ & $203 \pm 35(161-$ & 0.001 \\
& & $318)$ & & & $330)$ & \\
\hline $22: 00$ & $101 \pm 20$ & $162 \pm 37$ & 0.00003 & $96 \pm 20$ & $167 \pm 21$ & 0.00002 \\
\hline $2: 00$ & $93 \pm 17$ & $139 \pm 25$ & 0.00004 & $86 \pm 11$ & $152 \pm 33$ & 0.001 \\
\hline
\end{tabular}

Results are presented as mean \pm SD. Statistically significant results are in bold 


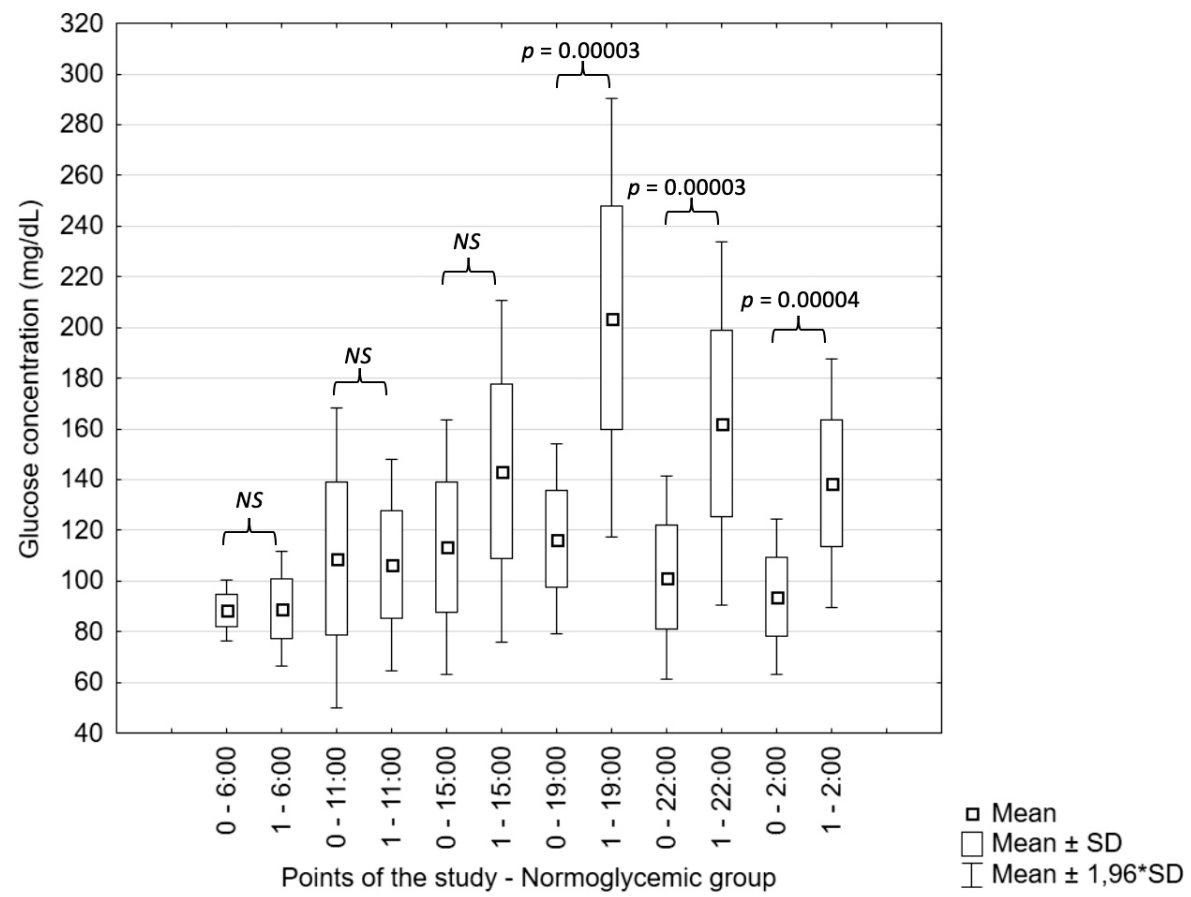

Figure 1. Glucose concentrations during intravenous methylprednisolone pulse $(500 \mathrm{mg})$ in normoglycaemic patients. NS nonsignificant. 0-6:00 day before the pulse, measurement at 6:00, 1-6:00 day of the pulse, measurement at 6:00,0-11:00 day before the pulse, measurement at 11:00, 1-11:00 day of the pulse, measurement at 11:00, 0-15:00 day before the pulse, measurement at 15:00, 1-15:00 day of the pulse, measurement at 15:00, 0-19:00 day before the pulse, measurement at 19:00, 1-19:00 day of the pulse, measurement at 19:00, 0-22:00 day before the pulse, measurement at 22:00, 1-22:00 day of the pulse, measurement at 22:00, $0-2: 00$ day before the pulse, measurement at 2:00, 1-2:00 day of the pulse, measurement at 2:00.

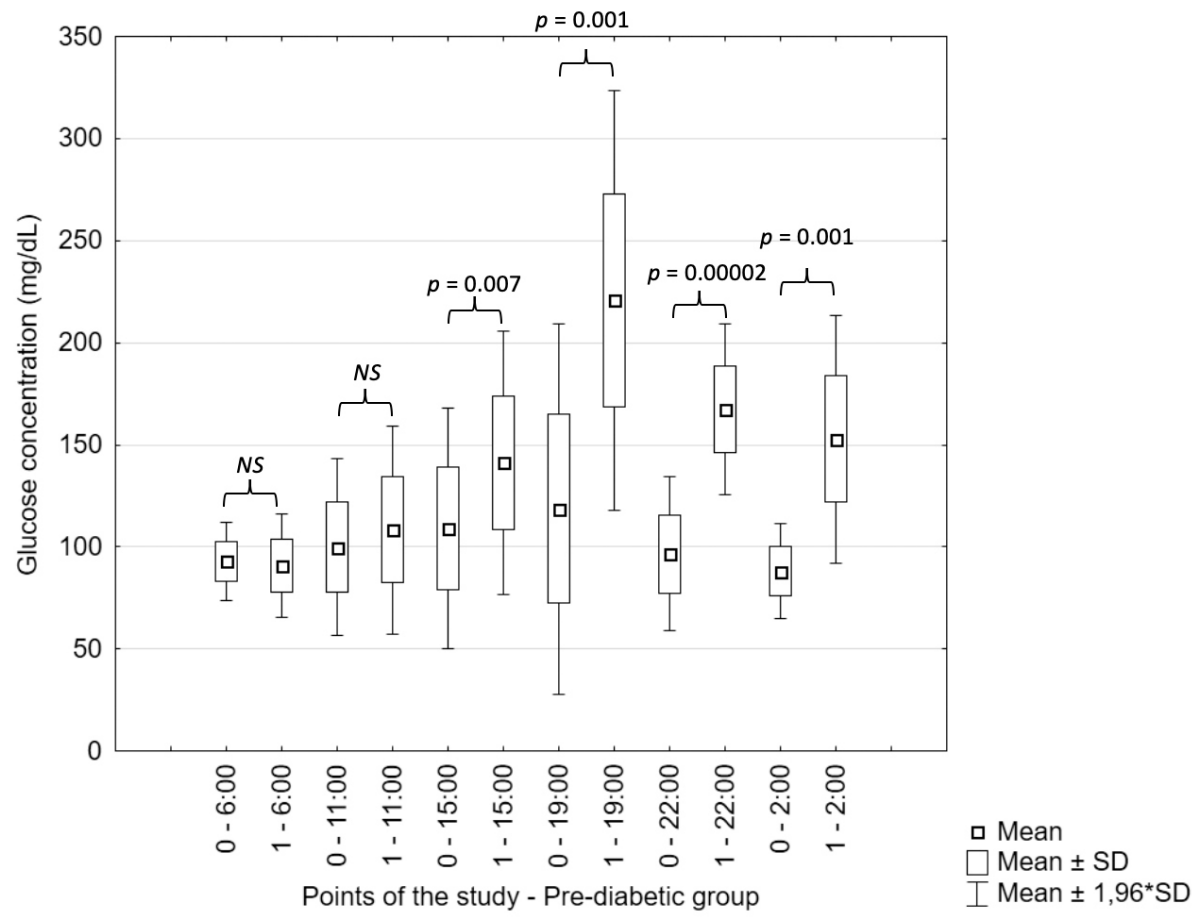

Figure 2. Glucose concentrations during intravenous methylprednisolone pulse $(500 \mathrm{mg})$ in pre-diabetic patients. NS non-significant. $0-6: 00$ day before the pulse, measurement at 6:00, 1-6:00 day of the pulse, measurement at 6:00, $0-17: 00$ day before the pulse, measurement at 11:00, 1-11:00 day of the pulse, measurement at 11:00, 0-15:00 day before the pulse, measurement at 15:00, 1-15:00 day of the pulse, measurement at 15:00, $0-19: 00$ day before the pulse, measurement at 19:00, 1-19:00 day of the pulse, measurement at 19:00, $0-22: 00$ day before the pulse, measurement at 22:00, 1-22:00 day of the pulse, measurement at 22:00, $0-2: 00$ day before the pulse, measurement at 2:00, 1-2:00 day of the pulse, measurement at 2:00 


\section{Short-term influence on single}

IVMP pulse on glycaemia

Detailed outcomes of capillary blood glucose for the IVMP pulse are shown in Table 3 . In the normoglycaemic group, we observed a statistically significant increase in capillary blood glucose levels on the day of pulse administration at 19:00, 22:00 and 2:00 (Figure 1 and Table 3). In the pre-diabetic group, we observed a significant increase in capillary blood glucose levels on the day of pulse administration at 15:00, 19:00, 22:00 and 2:00 (Figure 2 and Table 3). The highest increase in capillary blood glucose compared to the glucose concentration in both groups was observed on the day before the pulse at 19:00, which is 8 hours after the start of the IVMP infusion and 4 hours after its end.

A comparative analysis did not show statistically significant differences between the observed increases in glycaemia between two groups. Detailed outcomes are presented in Table 4 and Figure 3.

\section{Discussion}

Hypercortisolism, both endogenous and exogenous, is associated with an increased risk of hyperglycaemia and diabetes mellitus, hence, may occur during the for therapy with oral GCs [21]. However, the influence of therapy with IVMP on glycaemic control is not conclusive, with only a few studies conducted regarding this topic. The results of these studies are summarised in Table 1.

Feldman-Billard et al. [12] and Perez et al. [14] assessed morning fasting glucose one day after IVMP administration, observing a $50 \%$ and $68 \%$ increase, respectively. Unfortunately, in both studies, the groups of patients were not homogeneous, with patients receiving IVMP due to different indications and varying doses. The studies included patients without diagnosed diabetes mellitus, but they were not divided into two groups (patients with normoglycaemia vs patients with pre-diabetes). Furthermore, both lacked information wheth-

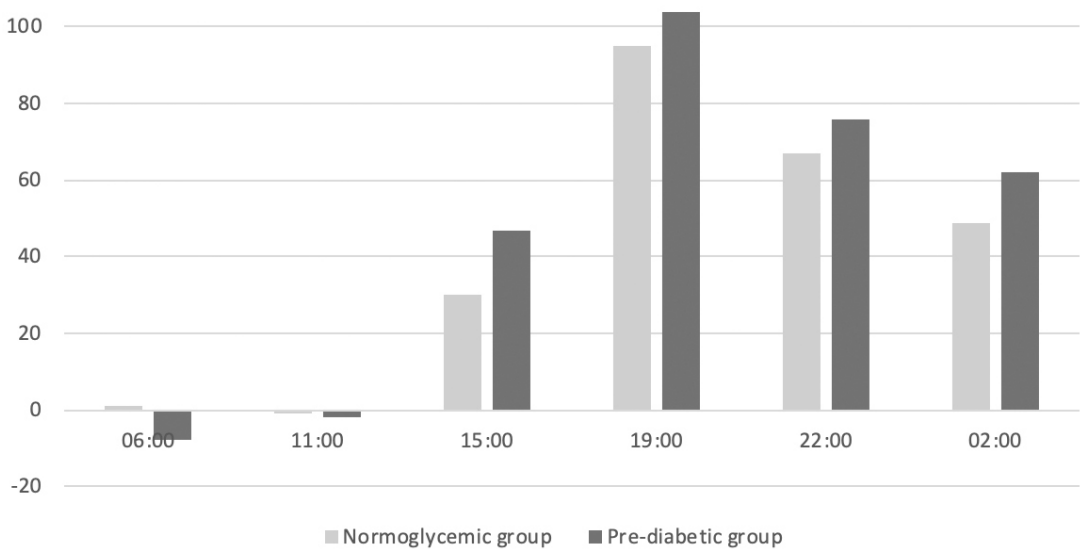

Figure 3. Average increase in glucose concentration at a given measurement point on the day of the intravenous methylprednisolone pulse administration compared to average glucose concentration at the same time of day before

Table 4 Average increase in glucose concentration at a given measurement point on the day of intravenous methylprednisolone pulse $(0.5 \mathrm{~g})$ administration compared to average glucose concentration at the same time of day before

Average increase in glucose concentration

\begin{tabular}{lccc}
\hline Time of measurement & Normoglycaemic group & Pre-diabetic group & $p$-value \\
\hline 6:00 & 1 & -7.5 & 0.2 \\
\hline 11:00 & -1 & -2 & 0.9 \\
\hline 15:00 & 30 & 47 & 0.5 \\
\hline 19:00 & 95 & 104 & 0.7 \\
\hline $22: 00$ & 67 & 76 & 0.6 \\
\hline 2:00 & 49 & 62 & 0.4 \\
\hline
\end{tabular}

Results are presented as mean. No results were statistically significant 
er patients were taking other medications that may affect glycaemia or whether steroids were given at a fixed time. Moreover, in both studies, glycaemia was controlled only in the morning and no measurements were taken during the day.

While Feldman-Billard et al. [12] suggested that the effect of the IVMP therapy on glucose tolerance in patients without DM is transient and has no clinical relevance, thus these patients do not need any monitoring of blood glucose levels or glucose-lowering treatment, Perez et al. [14] stated that there is evidence that acute hyperglycaemia is a cardiovascular risk factor, independently of the presence of previous diabetes, so patients without DM should be monitored and further longterm studies are necessary to identify clinical significance. None of these studies evaluated glucose levels at the time of day when they are most affected, which may explain the controversy.

There is only one study [16] concerning patients without diabetes receiving IVMP pulse therapy in which glucose levels were monitored during the day of the treatment. Unfortunately, the study group was small, consisting of five patients. Regardless, it was noted that glycaemia increased 2-3 hours after IVMP pulse administration, lasting for 12 hours and reaching a peak after dinner, or about 10 hours after administration of the IVMP. Glucose levels exceeded 200 $\mathrm{mg} / \mathrm{dl}$ after dinner in all patients (ranged from 240 to 293), then gradually decreased until morning.

The present study is unique in that the analysed group of patients was homogenous, with patients receiving IVMP at the same dose due to the same indication. IVMP infusion was administered at the same time and lasted for the same period of time for each patient. Also, patients who received medications that may affect blood glucose levels were excluded. Moreover, six daily capillary blood glucose measurements at fixed times (glycaemic profile) were performed to assess glycaemia at the time that it would be most affected. Furthermore, normoglycaemic and pre-diabetic patients were compared.

In this study, measurements of capillary blood glucose during the day of administration of IVMP pulse in comparison to the day before the drug infusion in both normoglycaemic and pre-diabetic patients showed a significant increase of glucose levels 4 hours after the start of IVMP pulse administration, reaching a peak at about 8 hours. At its peak, the mean levels of glucose were $200 \mathrm{mg} / \mathrm{dl}$ in both subsets (ranging from 130 to 318 and 161 to 330 in the normoglycaemic and pre-diabetic groups, respectively). Then, after this glucose peak, glucose levels in subsequent measurements gradually decreased, suggesting that the hyperglycaemic effect of IVMP pulse therapy develops at least 4 hours after the beginning of IVMP pulse administration, achieving a peak 4 hours later, then gradually decreasing. There was no difference between non-diabetic and pre-diabetic patients.

The most important question, however, is whether such a high increase in glucose is of clinical importance, especially considering the whole cycle of IVMP therapy with 12 weekly repeated infusions. Is the administration of glucose-lowering agents required?

The present study has some limitations. First, glucose measurements were derived from capillary blood using a glucose meter and not from serum glucose measurements. Moreover, the study was designed with a relatively small number of patients and included overweight and obese patients, patients did not receive standardised meals, and HOMA-IR was not determined prior to treatment to exclude patients with insulin resistance, all of which may affect glucose levels. Finally, we assessed only the short-term effect of one IVMP pulse administration on glucose levels, not the long-term impact of a whole cycle of IVMP therapy, which consists of 12 pulses. Also, we did not measure $\mathrm{HbA1c}$ and glucose tolerance with OGTT after therapy, hence, further research is required to assess the long-term impact.

In conclusion, methylprednisolone in a high intravenous dose has a tremendous impact on blood glucose levels in normoglycaemic and prediabetic patients on the day of drug administration.

\section{Data availability statement}

The data that support the findings of this study are available from the corresponding author upon reasonable request.

\section{Acknowledgements}

Conflict of interest statement

The authors declare no conflict of interest.

\section{Funding sources}

There are no sources of funding to declare. 


\section{References}

1. Boumpas DT, Chrousos G, Wilder R, Cupps T, Balow J. Glucocorticoid Therapy for Immune-Mediated Diseases: Basic and Clinical Correlates. Annals of Internal Medicine. 1993 Dec 15;119(12):1198-208. https:// doi.org/10.7326/0003-4819-119-12-19931215000007

2. Miśkiewicz P, Kryczka A, Ambroziak U, Rutkowska B, Główczyńska R, Opolski G, Kahaly G, Bednarczuk $T$. Is high dose intravenous methylprednisolone pulse therapy in patients with Graves' orbitopathy safe?. Endokrynol Pol. 2014;65(6):402-13. https://doi. org/10.5603/EP.2014.0056

3. Bartalena L, Baldeschi L, Boboridis K, Eckstein A, Kahaly GJ, Marcocci C, Perros P, Salvi M, Wiersinga WM. The 2016 European Thyroid Association/ European Group on Graves' Orbitopathy Guidelines for the Management of Graves' Orbitopathy. European Thyroid Journal. 2016;5(1):9-26. https://doi. org/10.1159/000443828

4. Stiebel-Kalish $H$, Robenshtok $E$, Hasanreisoglu $M$, Ezrachi D, Shimon I, Leibovici L. Treatment Modalities for Graves' Ophthalmopathy: Systematic Review and Metaanalysis. The Journal of Clinical Endocrinology \& Metabolism. 2009 Aug 1;94(8):2708-16. https://doi.org/10.1210/jc.2009-0376

5. Marcocci C, Watt T, Altea MA, Rasmussen AK, FeldtRasmussen U, Orgiazzi J, Bartalena L, European Group of Graves' Orbitopathy. Fatal and non-fatal adverse events of glucocorticoid therapy for Graves' orbitopathy: a questionnaire survey among members of the European Thyroid Association. European Journal of Endocrinology. 2012 Feb;166(2):247-253. https://doi.org/10.1530/eje-11-0779

6. Moleti M, Giuffrida G, Sturniolo G, Squadrito G, Campennì $A$, Morelli $S$, Puxeddu $E$, Sisti $E$, Trimarchi $F$, Vermiglio $F$, Marinò $M$. Acute liver damage following intravenous glucocorticoid treatment for Graves' ophthalmopathy. Endocrine. 2016 Mar 22;54(1):259268. https://doi.org/10.1007/s12020-016-0928-3

7. Miśkiewicz P, Milczarek-Banach J, Rutkowska-Hinc B, Kondracka A, Bednarczuk T. High-dose intravenous methylprednisolone therapy in patients with Graves' orbitopathy is associated with the increased activity of factor VIII. Journal of Endocrinological Investigation. 2018 Jun 9;42(2):217-225. https://doi. org/10.1007/s40618-018-0907-z

8. Miskiewicz P, Milczarek-Banach J, Bednarczuk T, Opolski G, Glowczynska R. Blood Pressure Profile and $\mathrm{N}$-Terminal-proBNP Dynamics in Response to Intravenous Methylprednisolone Pulse Therapy of Severe Graves' Orbitopathy. International Journal of Molecular Sciences. 2018 Sep 26;19(10):2918. https://doi. org/10.3390/ijms19102918

9. Miśkiewicz P, Jankowska A, Brodzińska K, Milczarek-Banach J, Ambroziak U. Influence of Methylprednisolone Pulse Therapy on Liver Function in Patients with Graves' Orbitopathy. International Journal of Endocrinology. 2018 Oct 21;2018:1-9. https://doi. org/10.1155/2018/1978590

10. Suh S, Park MK. Glucocorticoid-Induced Diabetes Mellitus: An Important but Overlooked Prob- lem. Endocrinology and Metabolism. 2017;32(2):180. https://doi.org/10.3803/enm.2017.32.2.180

11. Clore J, Thurby-Hay L. Glucocorticoid-Induced Hyperglycemia. Endocrine Practice. 2009 Jul;15(5):469474. https://doi.org/10.4158/ep08331.rar

12. Feldman-Billard S, Lissak B, Benrabah R, Kassaei $R$, Héron $E$. Intravenous pulse methylprednisolone therapy in eye disease. Ophthalmology. 2003 Dec;110(12):2369-2371. https://doi.org/10.1016/ s0161-6420(03)00818-2

13. Feldman-Billard S, Lissak B, Kassaei R, Benrabah R, Héron E. Short-term tolerance of pulse methylprednisolone therapy in patients with diabetes mellitus. Ophthalmology. 2005 Mar;112(3):511-515. https:// doi.org/10.1016/j.ophtha.2004.10.032

14. Perez TH, de Ossio GM, Flores QD, Coria HM, Peña TA, Coria HM, Pérez CG, Peña PS. Glucose disturbances in non-diabetic patients receiving acute treatment with methylprednisolone pulses. Rev Assoc Med Bras (1992). 2012 Jan-Feb;58(1):125-8. Rev Assoc Med Bras (1992). 2012 Jan-Feb;58(1):125-8. PMID 22392327

15. Martinez Martinez M, Abud-Mendoza C, MartínezLozano J, Acevedo-Castañeda E, Herrera-van Oostdam D. AB1025 Glycemia and Systemic Blood Pressure in Patients Who Receive Corticosteroid Pulse Therapy. Annals of the Rheumatic Diseases. 2016 Jun;75(Suppl 2):1252.2-1252. https://doi.org/10.1136/ annrheumdis-2016-eular.6082

16. Tanaka K, Okada Y, Mori H, Torimoto K, Arao T, Tanaka Y. The Effects of Mitiglinide and Repaglinide on Postprandial Hyperglycemia in Patients Undergoing Methylprednisolone Pulse Therapy. Internal Medicine. 2018;57(1):65-70. https://doi.org/10.2169/ internalmedicine.9013-17

17. Loader J, Montero D, Lorenzen C, Watts R, Méziat C, Reboul C, Stewart S, Walther G. Acute Hyperglycemia Impairs Vascular Function in Healthy and Cardiometabolic Diseased Subjects. Arteriosclerosis, Thrombosis, and Vascular Biology. 2015 Sep;35(9):20602072. https://doi.org/10.1161/atvbaha.115.305530

18. Yang Z, Laubach VE, French BA, Kron IL. Acute hyperglycemia enhances oxidative stress and exacerbates myocardial infarction by activating nicotinamide adenine dinucleotide phosphate oxidase during reperfusion. The Journal of Thoracic and Cardiovascular Surgery. 2009 Mar;137(3):723-729. https://doi. org/10.1016/j.jtcvs.2008.08.056

19. Lemkes B, Hermanides J, Devries J, Holleman F, Meijers J, Hoekstra J. Hyperglycemia: a prothrombotic factor?. Journal of Thrombosis and Haemostasis. 2010 May 12;8(8):1663-1669. https://doi.org/10.1111/ j.1538-7836.2010.03910.x

20. Cosentino F, Grant PJ, Aboyans V, Bailey CJ, Ceriello A, Delgado V, Federici M, Filippatos G, Grobbee DE, Hansen TB, Huikuri HV, Johansson I, Jüni P, Lettino M, Marx N, Mellbin LG, Östgren CJ, Rocca B, Roffi M, Sattar N, Seferović PM, Sousa-Uva M, Valensi P, Wheeler DC, Piepoli MF, Birkeland KI, Adamopoulos S, Ajjan R, Avogaro A, Baigent C, Brodmann M, Bueno $\mathrm{H}$, Ceconi $\mathrm{C}$, Chioncel $\mathrm{O}$, Coats $\mathrm{A}$, Collet J, Collins P, Cosyns B, Di Mario C, Fisher M, Fitzsimons D, Hal- 
vorsen S, Hansen D, Hoes A, Holt RIG, Home P, Katus HA, Khunti K, Komajda M, Lambrinou E, Landmesser U, Lewis BS, Linde C, Lorusso R, Mach F, Mueller C, Neumann F, Persson F, Petersen SE, Petronio AS, Richter DJ, Rosano GMC, Rossing P, Rydén L, Shlyakhto E, Simpson IA, Touyz RM, Wijns W, Wilhelm M, Williams B, Aboyans V, Bailey CJ, Ceriello A, Delgado $V$, Federici M, Filippatos G, Grobbee DE, Hansen TB, Huikuri HV, Johansson I, Jüni $P$, Lettino $M$, Marx N, Mellbin LG, Östgren CJ, Rocca B, Roffı M, Sattar N, Seferović PM, Sousa-Uva M, Valensi P, Wheeler DC, Windecker S, Aboyans V, Baigent C, Collet J, Dean V, Delgado V, Fitzsimons D, Gale CP, Grobbee DE, Halvorsen S, Hindricks $G$, lung $B$, Jüni $P$, Katus $H A$, Landmesser $\mathrm{U}$, Leclercq $\mathrm{C}$, Lettino $\mathrm{M}$, Lewis BS, Merkely B, Mueller C, Petersen SE, Petronio AS, Richter DJ, Roffi M, Shlyakhto E, Simpson IA, Sousa-Uva M, Touyz RM, Zelveian PH, Scherr D, Jahangirov T, Lazareva I, Shivalkar B, Naser N, Gruev I, Milicic D, Petrou
PM, Linhart A, Hildebrandt P, Hasan-Ali H, Marandi T, Lehto S, Mansourati J, Kurashvili R, Siasos G, Lengyel $C$, Thrainsdottir IS, Aronson D, Di Lenarda A, Raissova A, Ibrahimi P, Abilova S, Trusinskis K, Saade G, Benlamin H, Petrulioniene Z, Banu C, Magri CJ, David L, Boskovic A, Alami M, Liem AH, Bosevski M, Svingen GFT, Janion M, Gavina C, Vinereanu D, Nedogoda S, Mancini T, Ilic MD, Fabryova L, Fras Z, JiménezNavarro MF, Norhammar A, Lehmann R, Mourali MS, Ural D, Nesukay E, Chowdhury TA. 2019 ESC Guidelines on diabetes, pre-diabetes, and cardiovascular diseases developed in collaboration with the EASD. European Heart Journal. 2019 Aug 31;41(2):255-323. https://doi.org/10.1093/eurheartj/ehz486

21. Gulliford M, Charlton J, Latinovic R. Risk of Diabetes Associated With Prescribed Glucocorticoids in a Large Population. Diabetes Care. 2006 Nov 27;29(12):2728-2729. https://doi.org/10.2337/dc061499 